\title{
Anna Moraczewska, recenzja: Agencja Frontex w strefie Schengen. 10 lat doświadczeń, Artur Kuś, Anna Kosińska, Anna Szachoń-Przenny (red.), Wy- dawnictwo KUL, Lublin 2015, ss. 317.
}

Monografia Agencja Frontex w strefie Schengen. 10 lat doświadczeń jest wielopłaszczyznową i spójną analizą dotyczącą aktualnego problemu funkcjonowania granic zewnętrznych Unii Europejskiej z perspektywy działań jednej z agencji Unii Europejskiej odpowiedzialnej za bezpieczeństwo tych granic. Na jej aktualność składają się trzy elementy. Po pierwsze zjawisko masowej migracji cudzoziemców przede wszystkim z obszarów Afryki i Bliskiego Wschodu, po drugie dyskutowany ostatnio często problem funkcjonowania strefy Schengen wobec obecnych zagrożeń dla Unii oraz po trzecie kwestia ujęta w podtytule przez redaktorów, tj. dziesięć lat działalności Frontexu - Europejskiej Agencji Zarządzania Współpracą Operacyjną na Zewnętrznych Granicach Państw Członkowskich Unii Europejskiej, której siedziba znajduje się w Warszawie. Publikacja powstała w ramach aktywności Centrum Badań nad Europejskim Prawem i Polityką Migracyjną działającym na Wydziale Prawa, Prawa Kanonicznego i Administracji Katolickiego Uniwersytetu Lubelskiego Jana Pawła II przy Instytucie Europeistyki, a inicjatorami jej napisania byli pracownicy Katedry Prawa Unii Europejskiej KUL.

Na publikację składają się cztery rozdziały dotyczące płaszczyzn prawnej, społecznej i ekonomicznej działania Frontexu oraz rozdział poświęcony praktycznej aktywności Agencji. Stąd autorami zawartych w pracy artykułów są teoretycy i praktycy, co podnosi jej walor poznawczy. Jednocześnie są to osoby wywodzące się z różnych ośrodków naukowych i reprezentujące różne dyscypliny, dając możliwość spojrzenia na samą Agencję i jej działania z odmiennych perspektyw. Struktura monografii jest logiczna. Rozpoczyna ją rozdział poruszający kwestie formalno-prawne dotyczące genezy i miejsca Agencji w strukturze instytucjonalnej i prawnej Unii Europejskiej, jej celów oraz funkcji. W dwóch artykułach tego rozdziału przeanalizowano kluczowe zadania Frontexu, do których należy działalność wywiadowcza oraz analiza i zarządzanie ryzykiem na zewnętrznych granicach państw członkowskich. Ostatni artykuł dotyczy jednego z „najmłodszych” instrumentów nadzorowania granic zewnętrznych UE - EUROSUR-u, będącego sformalizowanym forum współpracy Frontexu i państw członkowskich. Autorka trafnie wskazała na potrzebę powołania tego systemu wobec wzrostu liczby i różnorodności zagrożeń dla funkcjonowania przestrzeni wolności, bezpieczeństwa i sprawiedliwości w Unii. Wydaje się, że w pierwszym rozdziale monografii mógłby znaleźć się jeszcze artykuł bezpośrednio definiujący relacje między Frontexem, strefą Schengen i geograficznym zakresem granic zewnętrznych Unii Europejskiej. Niektóre z tych informacji można odnaleźć w pozostałych tekstach, jednak kwestia ta poszerzyłaby analizę o jeszcze jeden aspekt i ukazałaby niejednorodność pojęcia granic zewnętrznych UE i jak się one mają do zakresu działalności terytorialnej Agencji. Być może ze względu na treść trafniejsze byłoby umieszczenie artykułu dotyczącego statusu prawno-ustrojowego Frontexu na pierwszej, a nie drugiej pozycji.

Rozdział drugi w całości jest poświęcony ochronie praw podstawowych w ramach działań Frontexu. Wobec problemu masowego napływu imigrantów, w tym uchodźców na terytorium UE, działania Frontexu wobec tych osób nabrały szczególnego znaczenia, a akcje ratownicze prowadzone przede wszystkim na Morzu Śródziemnym pokazują jednocześnie dylemat między działaniami podejmowanymi wobec tragedii ludzi uciekających z obszarów dotkniętych kon- 
fliktami lub o niskim poziomie życia a ochroną bezpieczeństwa wewnętrznego Unii. Pierwszy artykuł tego rozdziału to analiza na podstawie aktów prawnych UE działalności Frontexu w kontekście przestrzegania praw podstawowych. Autorka wskazała na wiele problemów decyzyjnych po stronie instytucji odpowiedzialnych za przestrzeganie tych praw i samą postawę Frontexu. Kolejny artykuł jest niejako logiczną kontynuacją poprzedniego z zawężeniem do grupy migrantów nieregularnych (in. nieudokumentowanych). Istotną kwestią w nim poruszaną jest wnikliwa analiza „konfliktu” między Frontexem a Instytucją Europejskiego Ombudsmana. $\mathrm{W}$ kolejnym artykule poruszono kwestie stosowania zasady non-refoulement $\mathrm{w}$ działaniach Agencji, która dotyczy zakazu odsyłania cudzoziemca z terytorium państwa do innego państwa, gdzie istniałoby zagrożenie dla jego życia lub mógłby być prześladowany czy torturowany. Jest to analiza prawna, wskazująca na ewolucję przepisów i działalności Frontexu wobec tej zasady. Ostatni artykuł dotyczy bezpośrednich działań Agencji i regulacji prawnych w dziedzinie wspólnych operacji powrotowych i wydaleń z terytorium Unii Europejskiej. Jest on istotnym uzupełnieniem poprzednich rozważań. Ze względu na wąski zakres, jakiego dotyczy rozdział drugi, można znaleźć kilka powtórzeń treści w zawartych w nim artykułach.

Autorzy trzeciego rozdziału skoncentrowali się na społecznych i ekonomicznych aspektach działalności Agencji. Pierwszy artykuł dotyczy pojawiających się wewnątrz Unii dysonansów w postrzeganiu imigrantów jako „siły roboczej” i „problemu społeczno-ekonomicznego” dla państw członkowskich. Praca mogłaby mieć jednak nieco bardziej syntetyczną formę i skoncentrować się na roli Frontexu w regulowaniu tego „dylematu”. Kwestię nielegalnej imigracji przedstawiono w kolejnym artykule i opisano problemy, na które narażeni są imigranci przebywający nielegalnie na terytorium państw Unii Europejskiej oraz wyjaśniono terminologię pojęć dotyczących tych osób. W artykule można jednak odnaleźć niejasność w stosowaniu określeń „,imigracja” i „migracja”. Jednocześnie ten istotny problem mógłby zostać umieszczony z perspektywy działań Agencji Zarządzania Współpracą Operacyjną na Zewnętrznych Granicach Państw Członkowskich Unii Europejskiej i jej metodologii rejestrowania nielegalnych imigrantów. Ponadto tytuł artykułu jest inny niż w spisie treści. Ostatnia praca trzeciego rozdziału porusza bardzo istotną kwestię powstania i funkcjonowania instrumentów finansowych wspierających działania Frontexu. Szczegółowo, a jednocześnie syntetycznie autor przedstawił istotę sposobu finansowania procesu zarządzania granicami zewnętrznymi oraz ewolucję samego mechanizmu.

Czwarty rozdział jest niemal w całości autorstwa praktyków zajmujących się bezpieczeństwem granic Unii Europejskiej. Pierwszy i trzeci artykuł opisuje płaszczyzny współpracy Straży Granicznej (SG) z Frontexem, w ujęciu ogólnym i z odniesieniem do Nadbużańskiego Oddziału SG. Obydwa zawierają informacje, które nie są powszechnie i często prezentowane w artykułach naukowych na temat bezpieczeństwa granic UE, tym samym istotna jest ich treść dla całkowitej wartości monografii. Drugi w kolejności artykuł przedstawia jedną z funkcji Agencji, jaką jest prowadzenie szkoleń. Autor zaprezentował ją z perspektywy współpracy Frontexu z Ośrodkiem Szkoleń Specjalistycznych Straży Granicznej działającym w Polsce w Lubaniu i na przykładzie wspólnie realizowanych projektów tych dwóch podmiotów. O ile sam artykuł wnosi ciekawe elementy do publikacji, nie nadano mu odpowiedniej struktury wymaganej dla artykułu naukowego. Ostatnia praca w czwartym rozdziale i całej publikacji kontynuuje temat funkcjonowania europejskiego systemu nadzorowania granic (EUROSUR) w ujęciu praktycznym. Autorka zaprezentowała złożoną sieć współpracy różnych unijnych agencji, w tym Frontexu, tworzących system bezpieczeństwa granic UE. W treści tekstu pojawił się niewielki błąd dotyczący długości granicy Polski z terytoriami państw trzecich, którą 
autorka, za innym autorem, uznała za najdłuższą. W rzeczywistości najdłuższy odcinek lądowej granicy zewnętrznej UE dzielą między sobą Szwecja i Norwegia - 1619 km. Jeżeli Norwegię zaliczymy do państw Schengen, wówczas tą najdłuższą lądową granicą będzie miała linia demarkacyjna między Finlandią i Rosją (1340 km). Natomiast sumarycznie Rumunia graniczy z trzema państwami spoza UE na długości $1457 \mathrm{~km}$, a Polska $1100 \mathrm{~km}$. Ten błąd nie zmienia jednak wartości poznawczej artykułu.

Większość artykułów prezentuje wysoką wartość merytoryczną, choć ich jakość jest zróżnicowana. Oczywiście niemożliwe byłoby uniknięcie pewnych powtórzeń ze względu na wąski przedmiot analizy, jednak Redaktorzy monografii powinni zapobiec pojawieniu się tych samych treści. Ostatni akapit artykułu pt. Społeczno-ekonomiczne uwarunkowania działalności FRONTEX-u jest niemal identyczny (w niektórych zdaniach całkowicie) jak drugi akapit z sekcji wniosków w pracy Przestrzeganie praw podstawowych $w$ działalności FRONTEX-u. O ile w pierwszym wypadku można znaleźć przypis, to w drugim już nie, jednak żaden $\mathrm{z}$ autorów nie umieścił danego tekstu w cudzysłowie, który jak można domniemywać, pochodzi z jednego źródła.

Publikacja, mimo kilku wskazanych powyżej uwag, jest godna polecenia i prawdopodobnie pierwsza w Polsce opisuje w tak szerokim ujęciu funkcjonowanie Europejskiej Agencji Zarządzania Współpracą Operacyjną na Granicach Zewnętrznych Państw Członkowskich Unii Europejskiej. Problem, który porusza, jest bardzo aktualny wobec dyskusji prowadzonych między państwami UE na temat przyszłości funkcjonowania strefy Schengen oraz poszerzenia kompetencji Frontexu wobec zagrożeń, które przenikają granice zewnętrzne Unii. Monografia prezentuje wysoki poziom merytoryczny i warsztatowy, jest napisana poprawnym językiem i w swojej strukturze zawiera elementy wymagane dla tego typu publikacji. 